\title{
SIX1 Gene Mutation
}

National Cancer Institute

\section{Source}

National Cancer Institute. SIX1 Gene Mutation. NCI Thesaurus. Code C158667.

A change in the nucleotide sequence of the SIX1 gene. 